\title{
GROWTH, INTERMOULT PERIOD AND WEIGHT OF EDIBLE PORTIONS OF GIANT PRAWN AND TIGER SHRIMP
}

\author{
Darti Satyani*)
}

\begin{abstract}
Since a prawn's body is covered by a hard cuticle, its growing mechanism develops through a moulting process. The development of the adult giant prawn and tiger shrimp during the moulting cycles has been studied. Giant prawns and tiger shrimps were reared individually in aquaria containing fresh and sea water respectively. The growth rates, intermoult periods and weights of edible portions of the animals were observed every two days.

The giant prawn has a slightly higher $(2.07 \mathrm{~g}$ of wet weight increment) growth per moulting compared to the tiger shrimp (1.95 g) wet weight increment. However, the intermoult period is longer (21.4 days versus 13 days) and the amount of edible portion is less (59.26\% versus $69.72 \%$ ). In commersial terms shrimp culture would be expected to be more viable than giant prawn culture.
\end{abstract}

KEYWORDS: Growth, fluctuation, premoulting, postmoulting, intermoult period, edible portion.

\section{INTRODUCTION}

Prawn and shrimp play an important role in Indonesian economics. Two of the key species cultured are the giant prawn (Macrobrachium rosenbergii) and tiger prawn (Penaeus monodon) which live in freshwater and seawater.

Since the body of the animal is covered with a hard cuticle, these animals grow through a moulting process called ecdysis. During the moulting process the old cuticle is divested, and is replaced by a new, initially weaker, cuticle. Depending on the animal's size, the new cuticle needs from a few hours up to a few days to develop (Wickins, 1976).

Yamaoka and Scheer (1970, cit Wickins, 1976) described the four main phases of moulting, as follows:

1) Proecdysis or premoulting phase is the period with the removal of the material from the old "shell" and the initial deposition of the new cuticle underneath;
2) Ecdysis or moulting is the process of casting off the cuticle followed by water uptake;

3) Metecdysis or postmoulting is the hardening phase of the new cuticle by the rearrangement of the organic material; and

4) Intermoult is the growth phase the replacement of fluid by tissue and accumulation of mineral and organic reserves.

The moulting process is controlled by hormones which are secreted from specific organs in the cephalothorax. The moulting frequency normally is influenced by size, and is independent to the age of the animal.

According to Choe (1971, cit Wickins 1976) the intermoult period of Macrobrachium rosenbergii and Penaeus japonicus has almost the same duration when the animals are of the same size. However, this period is still influenced by exogenous factors including food, temperature, light or the quality of the medium.

In this experiment, studies on the growth of giant prawn and tiger shrimp were conducted during their moulting cycle.

\footnotetext{
") Researcher of the Research Installation for Freshwater Fisheries, Depok.
} 


\section{MATERIAL AND METHODS}

The work was carried out in 50 litres aquaria provided with corner filters and $1.2 \mathrm{~cm}$ of gravel at the bottom. Giant prawn and tiger shrimp of $16-25 \mathrm{~g}$ each were reared in the appropriate media (freshwater for giant prawn, seawater for tiger shrimp) at one animal per aquarium. They were fed with commercially available pellets with $30 \%$ protein content. Shrimp samples (5-8 specimens/sample) were collected and observed every two days during one moulting cycle.

The methods of measurements were as follows.

(1) Growth, was obtained by measuring the wet weight increment (WWI) (Colman et al., 1981);

$$
W W I=W t-W o
$$

where:

$\mathrm{Wt}=$ Body weight at sampling time (g)

$\mathrm{Wo}=$ Body weight at the initial moult $(\mathrm{g})$

(2) Moulting duration/intermoulting period.

The moulting duration was measured directly after the occurrence of first moulting until the next moulting.

(3) Edible portion was measured as

$$
\frac{\text { Weight of edible flesh }}{\text { Total body weight }} \times 100 \%
$$

\section{RESULT AND DISCUSSION}

\section{Growth}

\section{(1) Giant prawn (Macrobrachium rosenbergii)}

Figure 1 illustrates giant prawn growth during one moulting cycle. The moulting phase was preceded by premoulting of about 2-3 days. During this time water absorption occurred increasing the body weight by $2.07 \mathrm{~g}$ from the initial moult (Table 1).

The postmoulting (3) phase was indicated by weight loss to $-1.05 \mathrm{~g}$, six days after moulting. Two weeks after moulting shrimp weight gain increased throughout the intermoult phase (20 days after the initial moulting).

The premoulting phase (1) was initialized by the inactively of the animals, characterized by cessation of feeding, thus causing a decrease in body weight. This process started 20 days after initial moulting and ended 2-3 days before the next moult (2) occured.

\section{(2) Tiger shrimp (Penaeus monodon)}

The premoulting phase (1) occured 2-3 days before the moulting process. The body weight increased at about $1.95 \mathrm{~g}$ during one moulting cycle.

Table 1. The intermoult period, wet weight increment (WWI) and edible portion of giant prawn during one moulting cycle (Mean $\pm \mathrm{SD}, \mathrm{N}=60$ ).

\begin{tabular}{cccc}
\hline $\begin{array}{c}\text { Sampling time } \\
\text { (day) }\end{array}$ & $\begin{array}{c}\text { WWI } \\
\text { (g) }\end{array}$ & $\begin{array}{c}\text { Edible portion } \\
\text { (\%) }\end{array}$ & Remark \\
\hline 0 & 0 & - & moult (initial moult) \\
2 & $1,16 \pm 0,10$ & $48,43 \pm 3,87$ & \\
4 & $-0,63 \pm 0,19$ & $52,09 \pm 5,11$ & \\
6 & $-1,05 \pm 0,20$ & $53,82 \pm 2,25$ & \\
8 & $-0,43 \pm 0,12$ & $51,87 \pm 4,28$ & \\
10 & $-0,10 \pm 0,02$ & $48,92 \pm 5,31$ & \\
12 & $-0,20 \pm 0,08$ & $52,49 \pm 2,17$ & \\
14 & $0,13 \pm 0,04$ & $51,08 \pm 2,24$ & \\
16 & $0,50 \pm 0,07$ & $52,16 \pm 5,18$ & \\
18 & $0,68 \pm 0,20$ & $49,12 \pm 3,98$ & \\
20 & $1,18 \pm 0,26$ & $58,79 \pm 4,41$ & \\
22 & $0,80 \pm 0,01$ & $56,83 \pm 2,51$ & \\
MII & $2,07 \pm 0,26$ & $59,26 \pm 0,15$ & moult (next moult) \\
\hline
\end{tabular}




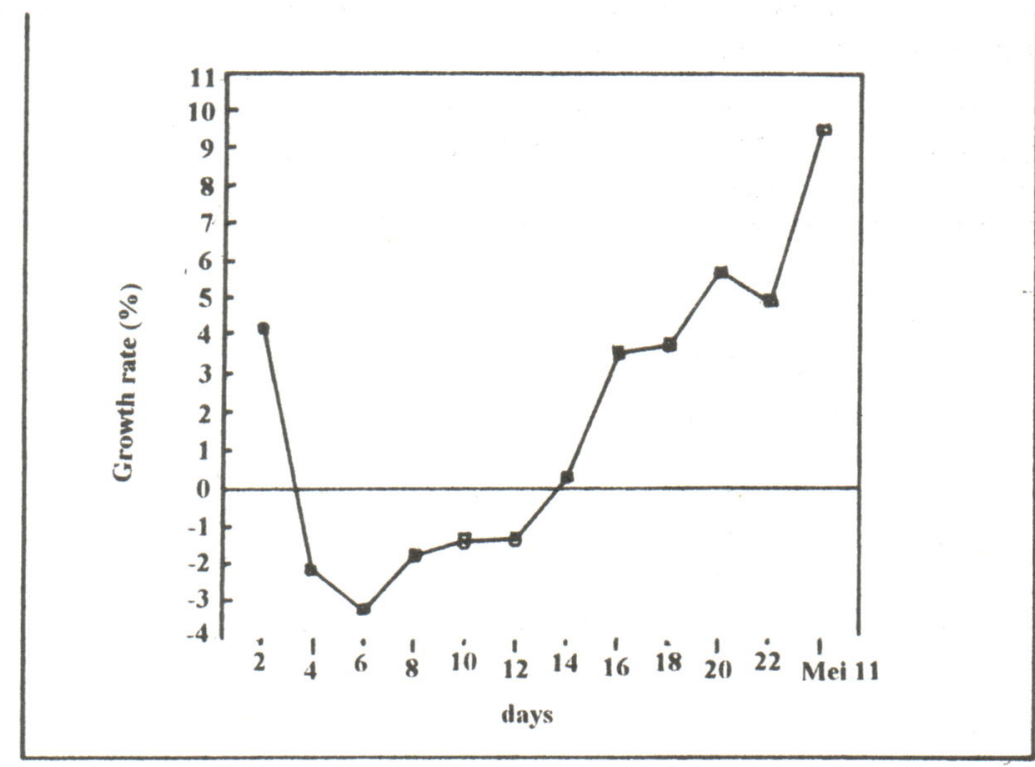

1. premoulting

2. moulting
3. postmoulting

4. intermoulting

Figure 1. Giant prawn growth in one moulting cycle.

The postmoulting phase with the lowest growth $(0.33 \mathrm{~g})$ was recorded two days after moulting (initial moult).

The intermoult phase terminated at $10^{\text {th }}$ day, and was indicated by decrease of shrimp body weight (Fig.2).

From a commercial point of view, this decreased weight is disadvantageous since production is always based on the body weight.

Protein, the primary material needed for the growth of the aquatic animals, is also used as an energy source. Significant amounts of energy are utilized for moulting.

The moulting cycle is part of the osmoregulation process between the internal tissue and the external medium. This process is very important, especially in ecdysis or moulting when the water absorption occurs. During this event, minerals and free amino acid (FAA) maintain the hemolymph osmotic pressure (Sandifer et al., 1975). The sources of the minerals are the feed and the water medium, whereas the FAA are derived from protein breakdown originated mainly from the feed (Lockwood, 1967). Since the giant prawn and tiger shrimp have dissimilar habitats, the energy sources for moulting will also be different.

The freshwater medium is not rich in minerals, therefore the role of FAA in the hemolymph for maintaining hyperosmotic pressure is important. The negative growth rate of the giant prawn in the postmoulting phase is due to the high energy needed for moulting and maintaining hyperosmotic pressure. While the prawn is in the inactive phase (exclude feeding), energy can not be produced from feeding, and most probably is produced by the breakdown of protein tissue. The growth rises again in the intermoult period, when the animals begin to feed actively again.

The phenomenon occurring in the tiger shrimp is rather different. Sea water is rich in minerals; so that the energy is needed to maintaining lower osmotic pressure. Large weight loss did not occur in tiger shrimp. Since the growth rate is estimated per day, the tiger shrimp has higher growth rates $(0.15 \pm 0.2 \mathrm{~g})$, than the giant prawn $(0.09 \pm 0.01 \mathrm{~g})$. Thus farmers need 5 months to culture giant prawn and only 4 months for tiger shrimp, in order to obtained the suitable market size $( \pm 25 \mathrm{~g})$ (Djajadiredja and Suharto, 1980, Satyani et al., 1991; Widjatmiko, 1989). 
Satyani, $D$.

Table 2. The intermoult period, wet weight increment (WWI) and edible portion of tiger shrimp in one moulting cycle observed every two days (Mean $\pm \mathrm{SD}, \mathrm{N}=56$ ).

\begin{tabular}{cccc}
\hline $\begin{array}{c}\text { Sampling time } \\
\text { (day) }\end{array}$ & $\begin{array}{c}\text { WWI } \\
(\mathbf{g})\end{array}$ & $\begin{array}{c}\text { Edible portion } \\
(\%)\end{array}$ & Remark \\
\hline 0 & 0 & & moult (initial moult) \\
2 & $0,33 \pm 0,04$ & $53,83 \pm 4,15$ & \\
4 & $0,73 \pm 0,07$ & $53,36 \pm 2,99$ & \\
6 & $0,90 \pm 0,12$ & $53,34 \pm 4,42$ & \\
8 & $0,89 \pm 0,07$ & $56,18 \pm 4,80$ & \\
10 & $1,48 \pm 0,30$ & $63,92 \pm 3,59$ & \\
12 & $0,87 \pm 0,14$ & $51,38 \pm 4,52$ & moult (next moult) \\
13 & $1,95 \pm 0,16$ & $69,72 \pm 3,06$ & \\
\hline
\end{tabular}

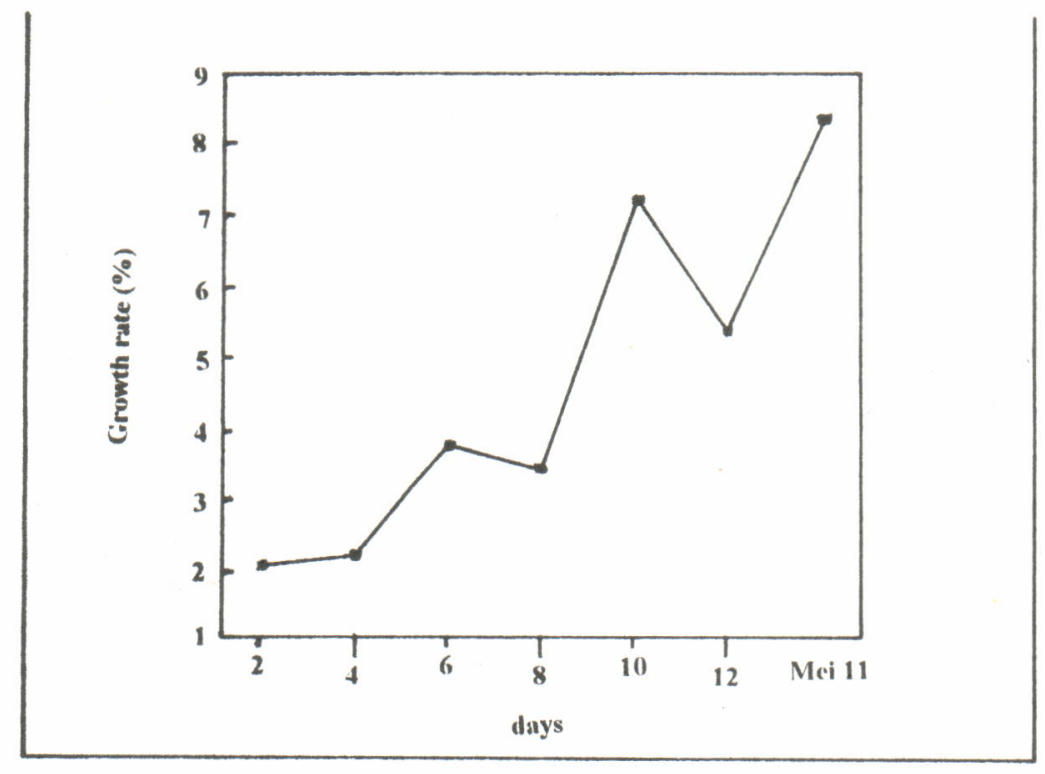

$\begin{array}{ll}\text { 1. premoulting } & \text { 3. postmoulting } \\ \text { 2. moulting } & \text { 4. intermoulting }\end{array}$

Figure 2. Tiger shrimp growth in one moulting cycle.

\section{Moulting Duration}

According to Choe (1971, in Wickins 1976) the relationship between the moulting duration and the animal size, based on observations of freshwater giant prawn and the marine shrimp Penaeus japonicus, can be illustrated as the regression equation: $\log$ moulting period (days) $=0,3114 \mathrm{x}$ (log live weight $(\mathrm{g}) \times 0,8405)$.
If the equation applies to this study, and the weight of the prawns is about 16-25 g/individual the moulting duration should be 16-19 days. This value is rather close to the moulting cycle period of the tiger shrimp, but not to that of the freshwater prawn wich has a longer moulting duration. Wickins (1976) and Segal and Roe (1975) found that the moulting cycle duration is influenced by temperature, animal size and feed availability. 
The temperature recorded in this study was about $26-29^{\circ} \mathrm{C}$. This was not significantly different from the temperature range used by Choe (1971, in Wickins 1976) which was $25-28{ }^{\circ} \mathrm{C}$. Prawn sizes and feed used were also the same.

Minerals addition of 1.5 to $2 \%$ to the feed (in giant prawn as well as in tiger shrimp) might shorten the moulting duration but would not increase the growth rates (Soeyoko, 1992; Soeyoko et al., 1993). The addition of minerals to the feed might induce higher hemolymph hyperosmotic pressure, and also the materials for building the new cuticle would be more easily available, which could increase the moulting frequency. Consequently the protein intake to the blood will decrease, and which produce negative growth. Higher hyperosmotic pressure also increases the moulting energy.

When giant prawns were cultured in water salinity of $10 \mathrm{ppt}$, giving a higher mineral content in the external medium, the condition produced significantly higher prawn production (Smith et al., 1980; Popper and Davidson, 1980; Silverthorn and Reese, 1978). According to Smith et al. (1980) giant prawns' blood osmotic pressure is about 17 . $18 \mathrm{ppt}$. Increasing minerals in the external medium reduce the osmotic differences between internal and external media and reduce moulting energy requirement. Protein available for increasing the growth rate is substantially greater. The wide fluctuation of prawn growth rates, as shown in Fig. 1 would probably not have occurred, if water of $10 \mathrm{ppt}$ salinity had been used.

Tiger shrimps were cultured in brackishwater with salinity of 25-30 ppt. However lower salinity of $15-20 \mathrm{ppt}$ could have produced better production (Suwirya et al., 1986; Haryanti, 1988). According to Poernomo (1980 in Suwirya et al., 1986) this phenomenon is also caused by the lower variations in the external and internal osmotic pressures that reduce the moulting energy.

The giant prawns produced less edible flesh $(48.43 \%-59.26 \%)$ compared with the tiger shrimp $(51.38 \%-69.72 \%)$ (Tables 1 and 2). The maximum percentage of the edible portion occuring in the postmoulting prawns, in accountable to the presence of soft cuticle in body covering. There is no significant difference in the percentage of the edible portion of prawns in the other phases of their moulting cycle $(\mathrm{P}<0.05)$.

\section{CONCLUSION}

Giant prawn growth rates are greater and have larger variations than to those of the tiger shrimp. However, the intermoult period of giant prawn is longer, the edible portion of giant prawn is smaller than that of the tiger shrimp. Finally the value $/ \mathrm{kg}$ of giant prawn is lower than that for shrimps. Therefore on balance shrimp cultivation must be expected to be more profitable to the farmer than giant prawn cultivation.

\section{AKNOWLEDGEMENT}

I greatly appreciate permission from Mrs. Soejoko to used data from her research on the "Mineralisation Process Study of Giant and Tiger Prawns Cuticle", supported by Research Intitute of University of Indonesia, and The World Bank Project.

\section{REFERENCES}

Colman J.A, V. Srisuwantach; S. Booyaratpalin and S. Chinabut. 1981. Pond management, water environment and fish grow out performance relationships in Clarias culture trials. NIFI. Bangkok, Thailand. 8-9.

Djajadiredja. R dan H. H. Suharto. 1980. Notes of result of Macrobrachium rosenbergii culture in ponds in Indonesia. Provisional Report IFS. Bangkok-Thailand $9: 201-211$.

Haryanti. 1988. Tanggapan Juvenil Penaeus monodon Fab yang diperlukan dengan penurun. an kadar garam terhadap konsumsi pakan. J. Penel. Budidaya Pantai 4(1): 13-20

Lockwood; A.P.M. 1967. Aspects of the Physiology of crustacea. W.H. Freeman and Company. San Fransisco. 32 p.

Popper. D.M and R. Davidson. 1980. An experiment in rearing freshwater prawns in brackishwater polyculture. Provisional Report IFS. BangkokThailand 9:245-246.

Sandifer; PA; J.S. Hopkins and T.I.J. Smith. 1975. Observation on salinity tolerance and osmoregulation in laboratory reared. Macrobrachium rosenbergii post-larva (Crustacea; Caridea). Aquaculture 6:103-114.

Satyani D; L.E. Hadie dan N. Mulyanti. 1991. Pengaruh budidaya terhadap udang galah 
(Macrobrachium rosenbergii). Bull. Penel. Perik. Darat. 10(3): 52-58.

Segal. E and A. Roe. 1975. Growth and behavior of post juvenile Macrobrachium rosenbergii (de $\mathrm{Man}$ ) in close confinement. Cal. State. Univ. Ca. 91324. 6p.

Silverthorn. S.U and A.M. Reese. 1978. Cold tolerance at three salinities in post larval prawns, Macrobrachium rosenbergii (de Man). Aquaculture. 15: 249-255.

Smith, TIJ.; P.A. Sandifer and W.E Jenkins. 1980. Growth and survival of prawns, Macrobrachium rosenbergii pond-reared at different salinities. Provisional Report. IFS. Bangkok-Thailand 9: 309-329.

Soeyoko. D.S, 1992. Pengaruh mineral dalam pertumbuhan udang galah. Laporan. Penel Univ. Ind. 30p.

Soeyoko. D.S; D. Satyani dan R Satoto. 1993 Pengaruh mineral dalam pertumbuhan udang windu. Laporan. Penel. Univ. Ind. 35p.

Suwirya. K; Z. Imran dan T. Rachmat. 1986. Pemeliharaan benur windu (Penaeus monodon) dengan berbagai tingkat kadar garam dalam kondisi laboratorium. Bull. Penel. Budidaya Pantai 2(122): 34-39.

Widjatmiko. 1989. Teknik pemberian pakan pada budidaya udang windu secara intensif. Prosiding Temu Karya Ilmiah Penelitian menuju Swasembada pakan ikan budidaya. Puslitbang Perikanan. Jakarta. 175-180.

Wickins. J.F. 1976. Prawn biology and culture. Oceanography. Macr. Biol. Ann. Rev. 14: 435. 507. 